Article

\title{
Application of Spectral Decomposition Technique to Delineate the Evolution of Karst on Carbonate Platforms of Central Luconia, Offshore Sarawak, Malaysia
}

\author{
Siti Sarah Ab Rahman 1,*(D), Maman Hermana Husen ${ }^{2} \mathbb{D}$, Grisel Jimenez Soto ${ }^{1} \mathbb{D}$, Saw Bing Bing ${ }^{1}$, \\ Nur Huda M Jamin ${ }^{1}$, Redwan Rosli ${ }^{1,3}$ and Michael C. Poppelreiter 1,4
}

1 South East Asia Clastic/Carbonate Research Laboratory, Institute of Hydrocarbon Recovery, Universiti Teknologi PETRONAS, Seri Iskandar 32610, Malaysia; griselpaola.jsoto@utp.edu.my (G.J.S.); bingbing.saw@utp.edu.my (S.B.B.); nurhuda.jamin@utp.edu.my (N.H.M.J.); redwan.rosli@eliis.fr (R.R.); M.Poppelreiter@SHELL.com (M.C.P.)

2 Centre for Subsurface Imaging, Institute of Hydrocarbon Recovery, Universiti Teknologi PETRONAS, Seri Iskandar 32610, Malaysia; maman.hermana@utp.edu.my

3 Eliis Sdn Bhd, Unit 23A-3, Binjai 8, Lorong Binjai, Kuala Lumpur 50400, Malaysia

4 Shell Kuwait Exploration and Production BV, P.O. Box 28487, Safat 13145, Kuwait

* Correspondence: sarah.rahman@utp.edu.my

\section{check for} updates

Citation: Ab Rahman, S.S.; Husen, M.H.; Soto, G.J.; Bing Bing, S.; Jamin, N.H.M.; Rosli, R.; Poppelreiter, M.C. Application of Spectral

Decomposition Technique to

Delineate the Evolution of Karst on Carbonate Platforms of Central Luconia, Offshore Sarawak, Malaysia. Appl. Sci. 2021, 11, 11627. https:// doi.org/10.3390/app112411627

Academic Editor: José A. Peláez

Received: 29 July 2021

Accepted: 26 October 2021

Published: 8 December 2021

Publisher's Note: MDPI stays neutral with regard to jurisdictional claims in published maps and institutional affiliations.

Copyright: (c) 2021 by the authors. Licensee MDPI, Basel, Switzerland. This article is an open access article distributed under the terms and conditions of the Creative Commons Attribution (CC BY) license (https:/ / creativecommons.org/licenses/by/ $4.0 /)$.
Abstract: Karstification in carbonate platforms of the Miocene age in Central Luconia province, offshore Sarawak, Malaysia, has been discussed since the onset of exploration and initial discoveries in the region, with over 200 mapped platforms to date. An extensive drilling program over the last decade confirmed the existence of karst during the drilling process where issues such as total loss circulation and bit drops were common. Karst in Central Luconia has been proposed by several authors; however, detailed quantitative description of the observed features have not yet been conducted. This study involves systematic mapping of loss circulation depths, chalkified/rubble/vuggy zones described from cores, and vugs of $>2 \mathrm{~mm}$ in size and moldic porosity observed on thin sections of the Jintan platform. These data supplement the interpretation of karst from multiple 3D seismic attributes. Seismic interpretation of the Jintan and M1 platforms revealed an extensive dendritic pattern which is on average 70-100 m deep and 3-5 km long, and circular geobodies of $1 \mathrm{~km}$ in width that exist on the upper part of the platform. Spectral decomposition, also known as time-frequency analysis, was used to enhance the interpretation of karst features on seismics within a specific wavelength. In this study, a comparison of three spectral decomposition methods applied on the 3D seismic cube of the Jintan and M1 platforms was undertaken to determine the method which allowed for better delineation of the karst features. The results show that the short-time Fourier transform (STFT) method using frequencies of 46,54, and $60 \mathrm{~Hz}$ delineated most of the karst features compared to the continuous wavelet transform (CWT) Morlet and CWT Ricker wavelet methods. This paper aims to discuss the dimensions, evolution and geometry of the karst features quantitatively on three selected karst horizons named "K1", "K2", "K3". Interpretation revealed that the dendritic karst features were found to be most prominent on the $\mathrm{K} 2$ horizon which lies below a conspicuous change of the external geomorphology of the platform. Backstepping of the platform margin by $12 \mathrm{~km}$ is observed in both platforms. Quantitative seismic interpretation shows that the karst observed in M1 platform is approximately $70-100 \mathrm{~m}$ deep, and the dendritic features are around 1-2 km in length and approximately $500 \mathrm{~m}$ wide; whereas, in the Jintan platform the dendritic features observed are up to $5 \mathrm{~km}$ in length with several $1 \mathrm{~km}$ wide circular/sinkhole features. More than 20 dendritic features orientated SE and NS were mapped mainly in the transitional area as well as the center of both platforms. The nature of the karst morphology in Central Luconia remains controversial; however, it is proposed to be of mixing zone karst origin.

Keywords: karst; geobodies; carbonate platform; attributes; spectral decomposition; volume calculation; Central Luconia; Malaysia 


\section{Introduction}

The glacio-eustatic sea level changes of the Quaternary have overprinted the dissolution record of many carbonate islands with multiple episodes of vadose, freshwater phreatic, mixing zone and marine phreatic conditions [1]. This phenomenon has led to karst development on the continuously emergent portions of carbonate platforms.

Karstification by definition is a process where carbonate rocks or other soluble components dissolve as a result of the infiltration of acidic water such as water-soluble carbon dioxide from the atmosphere and soil. The acidic water infiltrates through weak zones such as faults and fractures of carbonate platforms and creates distinct karst landforms such as sinkholes, dolines, caverns, and limestone pavements [2]. Ford and Williams [3] defined karst as comprising terrain with distinctive hydrology and landforms that arise from the combination of high rock solubility and well-developed secondary porosity (fracture). The development of karst takes place at irregular rates that typically include episodes of stagnation and even retrograde processes in which the evolution toward maturity is reversed [4].

Karst in carbonate platforms of Central Luconia has been discussed by many scholars since the 1980s [5-14]. Karstification in Central Luconia was first detected in the early days of exploration when most of the drilled wells encountered mud losses and other complications [7]. It was first postulated by Epting [5] from textures and geochemistry investigations of which suggested to be fresh water leaching during the periods of emergence.

However, further strontium analysis by Vahrenkamp [6] suggests that meteoric diagenesis had played a major role in the development of a well-connected karst system in the Central Luconia platform. Warrlich et al. [15] in their study on E11 field, Central Luconia, and the Malampaya field, offshore Philippines, revealed that meteoric leaching and cementation as well as late leaching created depositional-layer-conformable geobodies of high-porosity and low-porosity rocks. Further seismic interpretation supplemented with attribute analysis revealed prominent dendritic features on Central Luconia carbonate platforms and were studied by only a few authors, however, the karst features have never been quantitatively described in detail [5-12].

Understanding of the geometry and connectivity of karst is essential in field development, well management, and hydrocarbon recovery. Karst has a huge impact on the future development of hydrocarbon reservoirs such as well planning where karst causes problems with losses and completion length. Field production is also largely affected by karst as wells are likely to water-out quicker. In-place volume estimates might be inaccurate due to the nature of karst which may create substantial secondary porosity. Hence, there is a strong business case to map out karst in detail as an input for the field development plans for example [9].

The Carbonate Island Karst Model (CIKM) integrates the components that control the cave and karst development on carbonate islands, of which [16] states includes:

1. Dissolution aggressivity due to the mixing of fresh and salt water.

2. Mixing environments from freshwater lens movement resulted from quaternary glacioeustasy.

3. Presence of overprinting of glacioeustatic changes by local tectonic movements.

4. Eogenetic (diagenetically immature) carbonate rocks.

5. The classification of carbonate islands from simple to complex categories.

Larson and Mylroie [17] in their study on the relationship of island karst with respect to their area and perimeter revealed that subaerial island sizes influence the development of conduit caves in simple carbonate islands. Larger platforms are expected to have conduit and flank margin caves forming at the same time.

A major challenge for carbonate geology in both academia and industry is the need for detailed calibration with rocks or alternatively the use of numerical approaches such as synthetic seismic modelling [18]. Integrated studies between seismic, geological and petrophysical data has improved the understanding of the depositional history of carbon- 
ates, factors controlling reservoir heterogeneity, possible fluid flow models and reservoir characterization [19].

In this study, the occurrence of karst and the geometries of karst features observed in a Mega Platform of Central Luconia, offshore Malaysia, is discussed through the integration of cores, thin sections and seismic interpretation. This paper aims to provide quantitative interpretations as well as volumetric estimations of the mapped karst geobodies which were delineated using spectral decomposition techniques.

Spectral decomposition has been widely used to enhance seismic interpretation and improve the images of targeted geobodies. This technique was applied to highlight the stratigraphic features and also to extract architectural elements of the reef structure such as reef rim belt and karst related patterns [20].

The application of spectral decomposition has expanded rapidly over the past few years as a tool for the analysis of stratigraphic architecture for the interpretation of direct hydrocarbon indicators (DHIs) [21].

\section{Geological Setting}

The Central Luconia province located offshore Borneo, Malaysia, is covered by some 250 coral-rim carbonate buildups of Middle to Upper Miocene age [6].

The province is bounded by the extensional South China Basin to the north and the compressional Balingian Province to the south [5].

During the Oligocene and Middle Miocene, seafloor spreading in the South China Basin affected the continental crust to the south which led to the formation of a SW-NE trending horst-graben system. This tectonic set up controlled the distribution of reefal carbonate growth that perches on horst blocks [5].

According to [8], shallow water carbonate buildups in the Central Luconia province are Middle Miocene to Late Miocene in age. The interplay between eustatic sea-level, tectonism and clastic sediment supply is fundamental in the development of carbonate build-ups. The size and shape of the build-ups are mainly affected by subsidence and antecedent topography. Sea-level changes affected the architecture and facies distribution of buildups. Accumulation of clastics on top of the buildups eventually terminated the carbonate growth.

The buildup investigated is part of a Carbonate Mega Platform $(30 \times 50 \mathrm{~km})$ located to the northernmost extent of the Jintan High in the Central Luconia province [12,22]. Hydrocarbon accumulation is concentrated in several compartments in the uppermost layers of this Mega Platform.

Jintan and M1 fields were discovered on the Mega Platform and have been extensively characterized sedimentologically and stratigraphically [12]. Three major seismicstratigraphic horizons were distinguished and labeled as ' $\mathrm{K} 1$ ', ' $\mathrm{K} 2$ ' and ' $\mathrm{K} 3$ '. These layers were penetrated by Jintan-3 well. Conventional cores, thin sections and mud loss data were extracted from the well to describe attributes i.e., loss of drilling mud as a proxy for potential karstification.

It was noted that the depth of complete loss of drilling mud coincided with the interpreted seismic horizons that displayed features ascribed to karst. Core samples revealed characteristics indicative of dissolution and exposure such as chalkified texture. Integration of the core to well log data highlighted depths which often showed unusually high porosity readings between heavily karstified intervals on top of the lower carbonate sequence [22]. Karst features are particularly widespread in between the SU4 and SU5 sequence stratigraphic units as defined by [12]. The intervals were chosen to understand the geometry of the karst geobody. Figure 1 shows the location of Jintan and M1 fields as part of the Mega Platform in the northernmost region of the Central Luconia province. 


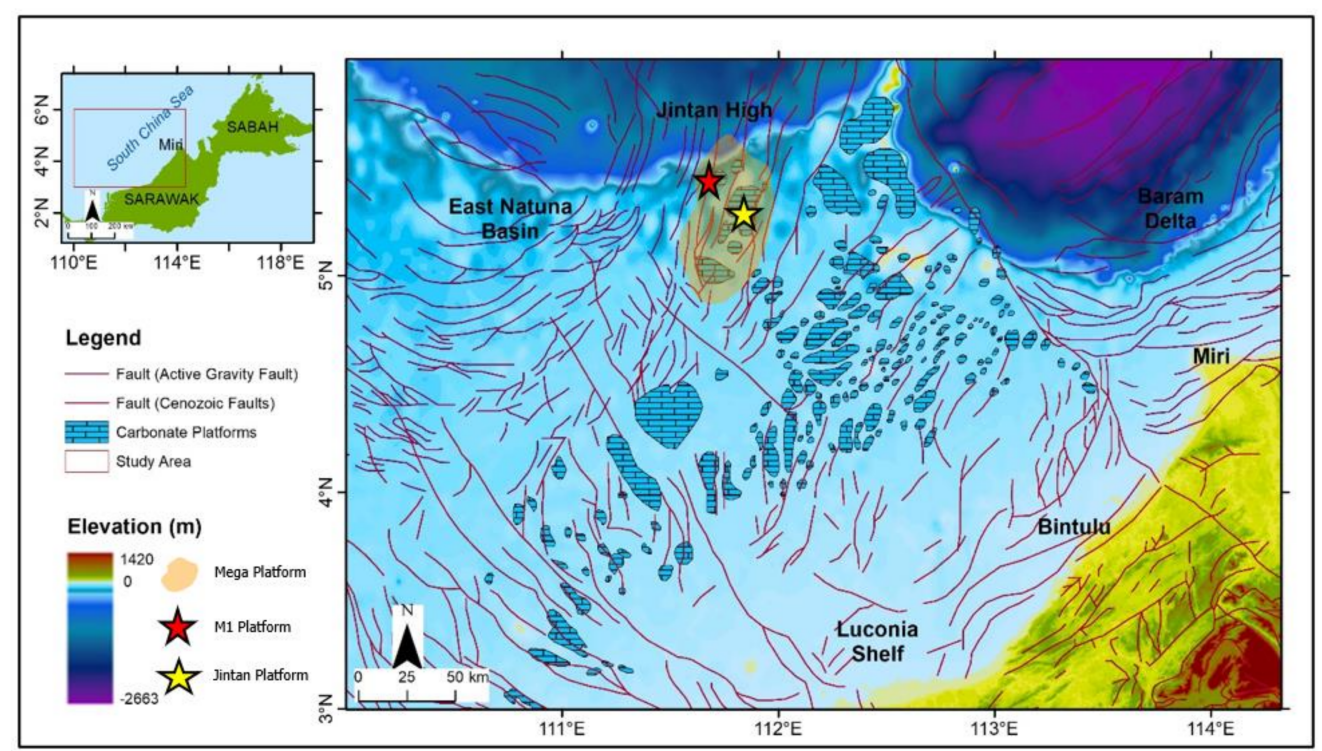

Figure 1. The location of Jintan and M1 platforms in Central Luconia province.

\section{Materials and Methods}

An integrated approach using multiscale data (Table 1) was utilized in this study and was crucial in order to understand the karst morphology in Jintan and M1 platforms.

Table 1. Summary of materials and methodology analysis for this study which involved multiscale soft and hard data.

\begin{tabular}{|c|c|c|}
\hline Materials & Description & Methodology \\
\hline Drilling data & $\begin{array}{l}\text { Final well reports of Jintan-1, } \\
\text { Jintan-2, Jintan-3 and M1-1 wells. }\end{array}$ & $\begin{array}{l}\text { Lost circulation depths recorded } \\
\text { to preliminary identify the depth } \\
\text { of possible karst in each platform. }\end{array}$ \\
\hline Well logs & $\begin{array}{l}\text { Gamma ray logs of Jintan-1, } \\
\text { Jintan-2, Jintan-3 and M1-1 wells. }\end{array}$ & Seismic to well-tie analysis. \\
\hline Thin Section & $\begin{array}{l}32 \text { units of Jintan- } 2 \text { thin sections } \\
38 \text { units of Jintan- } 3 \text { thin sections }\end{array}$ & $\begin{array}{l}\text { Identification of pore type and } \\
\text { cement related to dissolution } \\
\text { diagenesis to understand karst } \\
\text { morphology. }\end{array}$ \\
\hline Core data & $\begin{array}{l}84 \text { m of Jintan- } 2 \text { core and } 207 \mathrm{~m} \text { of } \\
\text { Jintan-3 core described. }\end{array}$ & $\begin{array}{l}\text { The depth of chalkified and } \\
\text { rubble intervals recorded. }\end{array}$ \\
\hline 3D Seismic & $\begin{array}{l}\text { Jintan \& M1 merged 3D cube } \\
\text { seismic }\end{array}$ & $\begin{array}{l}\text { Karst horizon interpretation. } \\
\text { Spectral decomposition } \\
\text { techniques application. }\end{array}$ \\
\hline
\end{tabular}

The $245 \mathrm{~km}^{2}$ Jintan 3D seismic cube was acquired between 1991 and 1992 with a grid spacing of $300 \mathrm{~m}$, meanwhile the M1 seismic cube was acquired between 2015 and 2016. The Jintan and M1 surveys were merged in this study for the purpose of horizon interpretation of both platforms. Four exploration wells i.e., Jintan-1, Jintan-2, Jintan-3 and M1-1, were utilized for seismic to well-tie analysis prior to horizon interpretation and also correlation between well markers and objective reflectors using available gamma ray logs (Figure 2).

The workflow used to analyse and interpret the 3D seismic volume in conjunction with core, well log and other data is shown in Figure 3. 


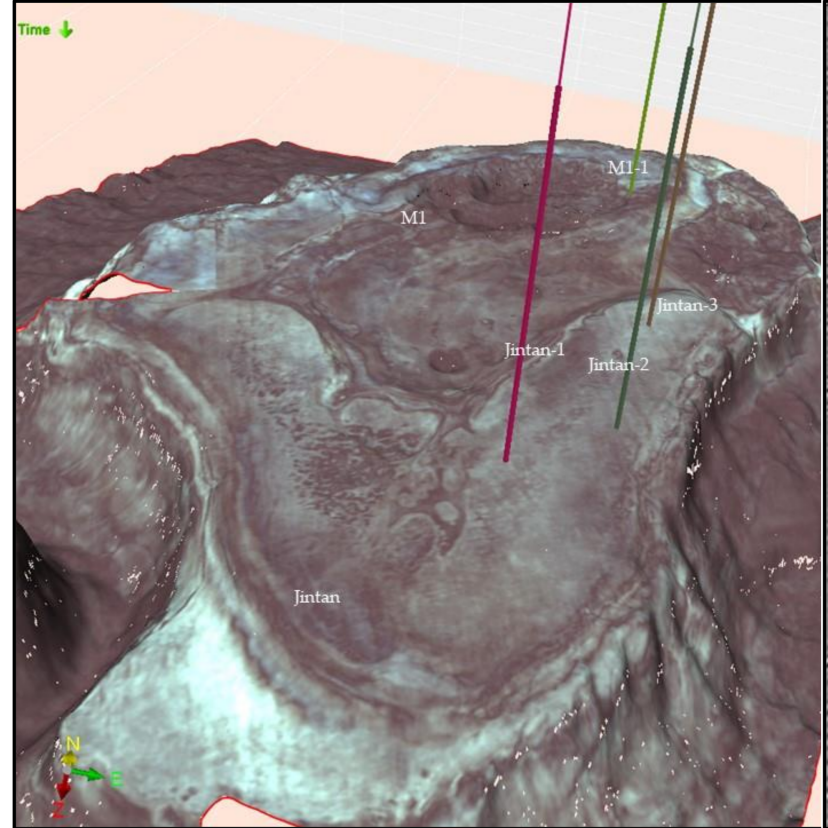

(a)

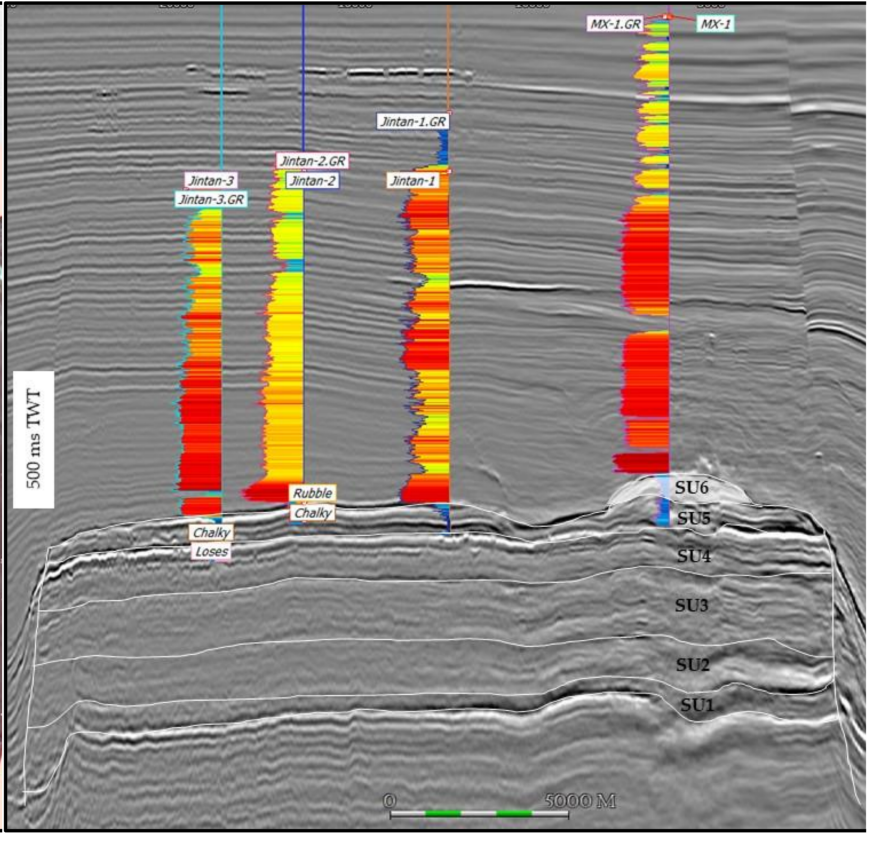

(b)

Figure 2. (a) 3D inline section showing Jintan and M1 fields and Jintan-1 and Jintan-2 wells. Annotated are the seismic units (SU1 to SU6) as interpreted by [12] (b) 3D image of the Mega Platform structure extracted from a coherency cube displaying the Jintan and M1 fields.

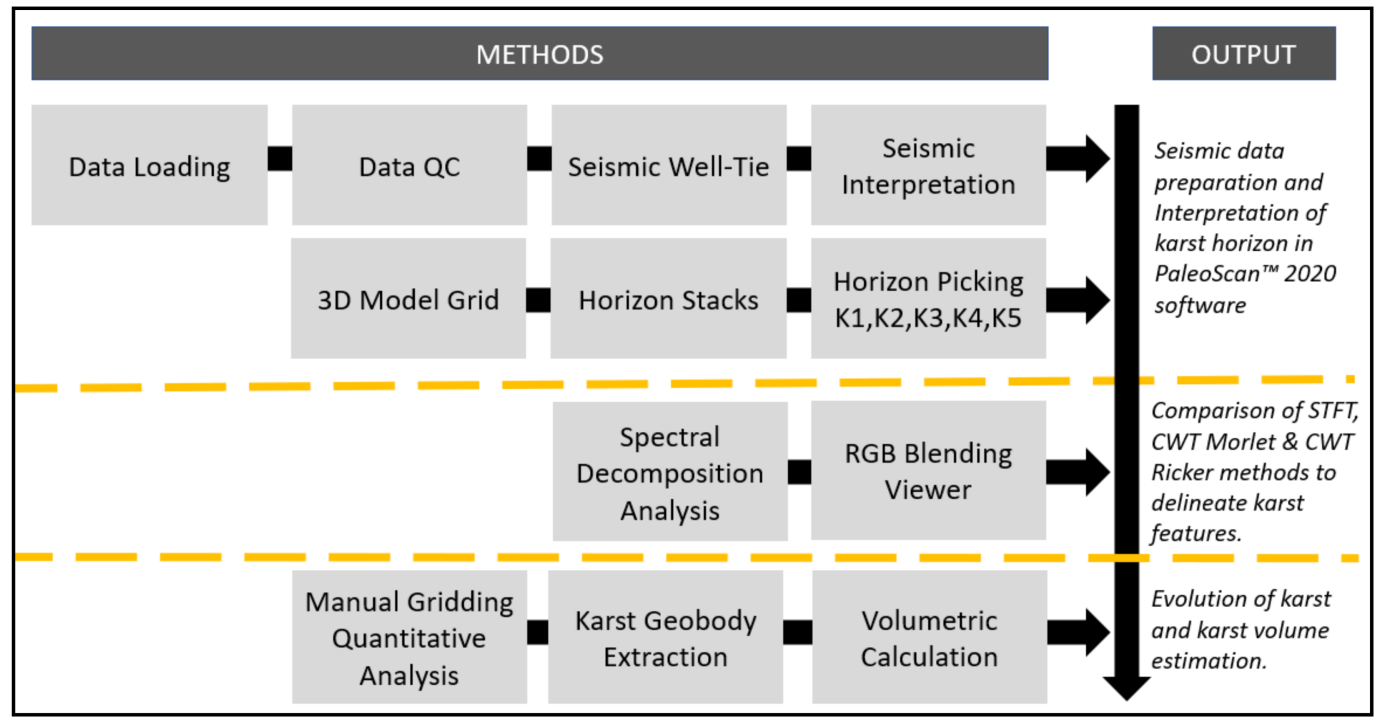

Figure 3. Methodology and workflow used for the interpretation of karst geobodies from 3D seismic using spectral decomposition techniques. Geobody extraction and volumetric calculation complemented the analysis to estimate the volume of the karst geobody in the Jintan and M1 fields.

Final well reports were studied to identify lost circulation reported during drilling and provide preliminary intervals of possible karst.

A total of 70 units of thin sections from the Jintan platform were analyzed for the identification of pore type and cement related to dissolution diagenesis relevant to understand karst morphology. In addition, cores with a total length of $291 \mathrm{~m}$ from Jintan-2 and Jintan-3 wells were described in detail to identify chalkified intervals as they are interpreted as karst due to intensive leaching related to mixing zone karstification [14].

The spectral decomposition technique allows seismic trace-based attributes to be created in order to better highlight geological features. The main purpose of this technique 
is to decompose the seismic signal into different energies corresponding to each frequency in the volume in order to create a spectrogram. By analyzing the spectrogram, it is possible to select several dominant associated frequencies corresponding to the geological target features. In combination with stratal slicing and RGB blending in PaleoScan ${ }^{\mathrm{TM}}$ software, this workflow can help facilitate the target detection based on the frequency imaging.

\subsection{Seismic Interpretation}

Seismic interpretation was conducted using PaleoScan ${ }^{\mathrm{TM}}$, in which horizons are generated based on a Relative Geological Time (RGT) model computed according to each seismic polarity: peak, trough, and zero crossing. The technology applied to generate the RGT is developed based on cost function minimization algorithms that depend on the distance and similarity of each seismic trace [23].

The algorithms allow automated tracking of each seismic reflector within the seismic volume (Figure 4). As a result, the horizons generated are consistent and continuous which will improve the imaging of the geological features.

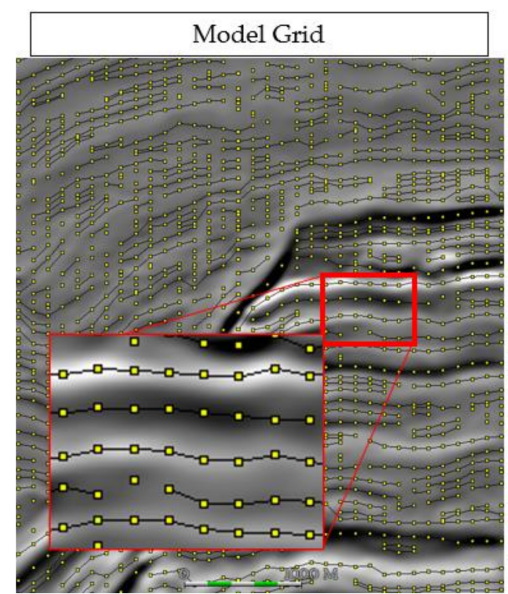

(a)

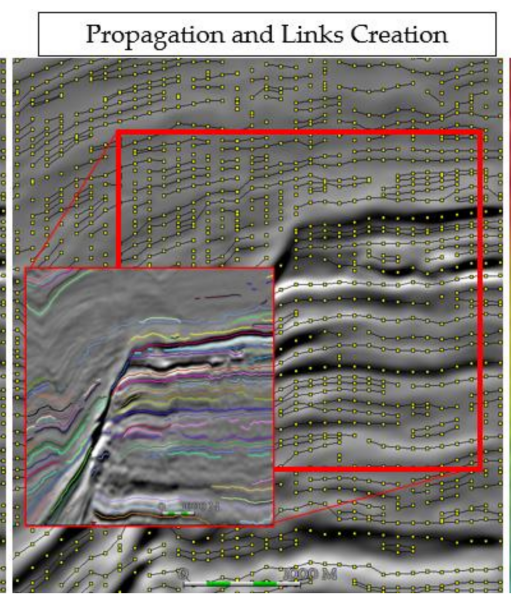

(b)



(c)

Figure 4. Modelling the relative geological time (RGT) modified from [23]. (a) Model-grid creation where each yellow node represents a small horizon patch with a limited size. (b) Links established in between nodes after propagation where the volume is composed of horizons with various size. (c) 3D continuous RGT model computed on the entire seismic volume based on the relationship of the nodes.

The continuity of the seismic horizons follows the chrono-stratigraphy of geological events and allows high precision of interpretation of the geological features [24]. Figure 5 shows how interpretations are more promising on horizon slicing compared to time slicing where the elongation and continuation of the karst geobodies can be seen clearly on the horizon slicing seismic.

\subsection{Spectral Decomposition}

In this analysis, three spectral decomposition methods were applied to the seismics to identify which methods could delineate the most prominent karst features. The frequencies were directly picked from the targeted high amplitude karst zone in seismics (Figure 6). Figure 7 shows the frequency picked window where the different methods of spectral decomposition techniques could be applied allowing the interpreter to pick frequencies of the targeted karst features. The three picked frequencies which represent low, mid and high are directly displayed as frequency decomposition by using RGB blending techniques (Figure 8). Co-rendering those frequencies with three colours i.e., red, green and blue, has enhanced the image of the karstic features. 

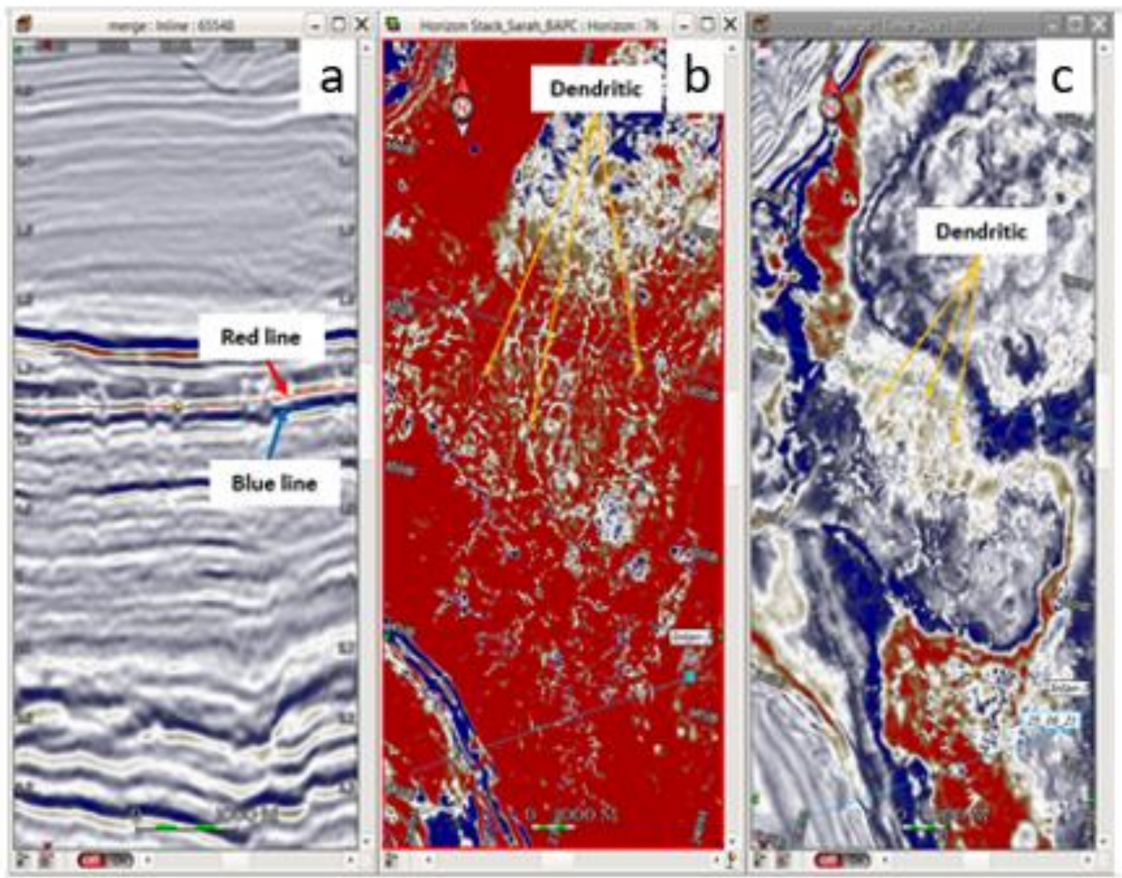

Figure 5. (a) Horizon slicing (red line) and time slicing (blue line) shown in the vertical seismic section. (b) shows Horizon slice (c) shows time slice. Both are applied to image the karst dendritic patterns. Image (b) delineates more prominent and shows the continuation of the karst geobody compared to the time slice image (c) which could mislead karst interpretation that should be avoided during the well planning decision.



Figure 6. Targeted dendritic pattern and high amplitude karst features shown in the red arrow for frequency picking. 


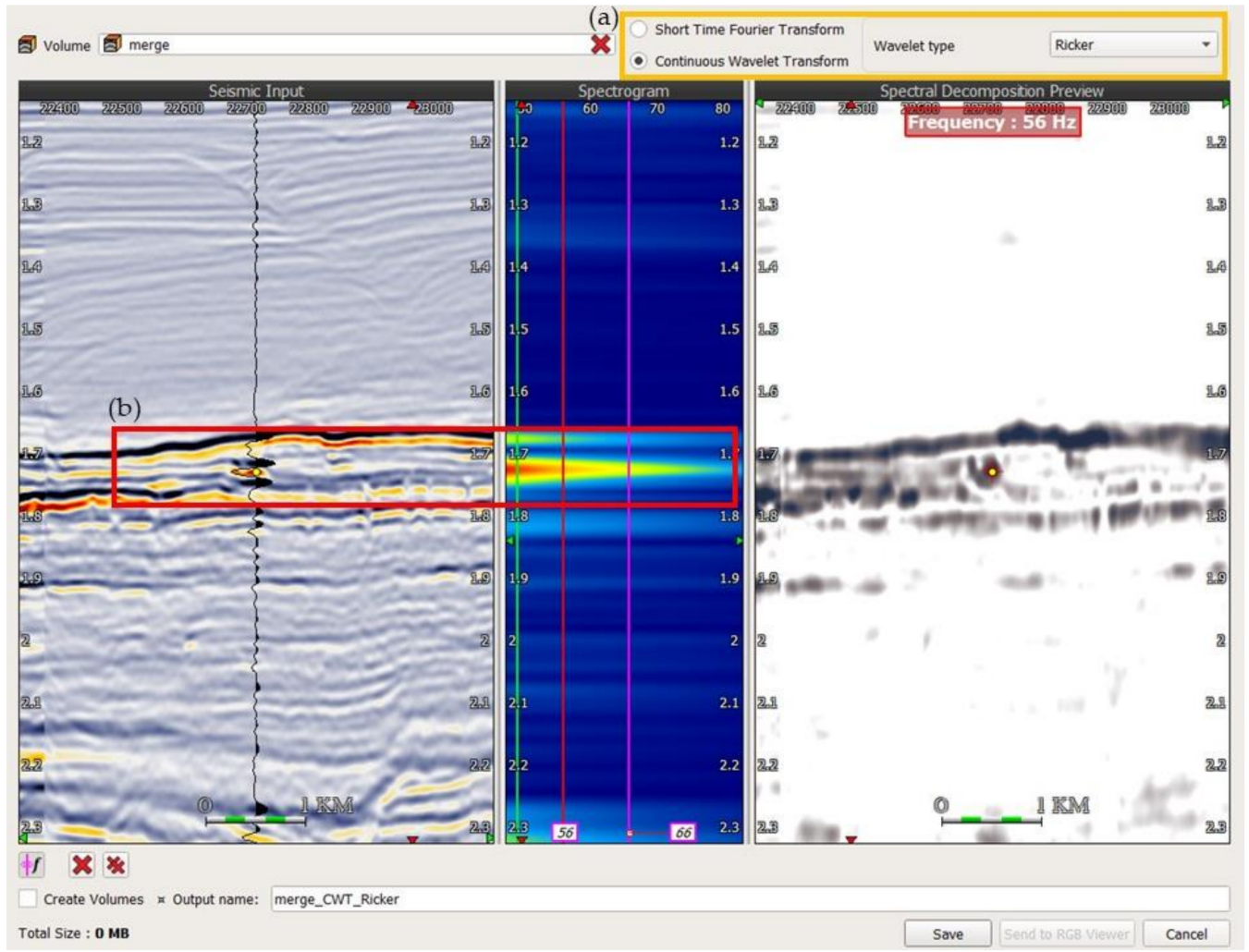

Figure 7. The frequency picked window which allows (a) Several methods of spectral decomposition. A simple method of short-time Fourier transform (STFT) and two methods of continuous wavelet transform (CWT), using Morlet or Ricker wavelets (b) Associated frequencies of the targeted karst geobody which can be directly picked in the spectrogram viewer.

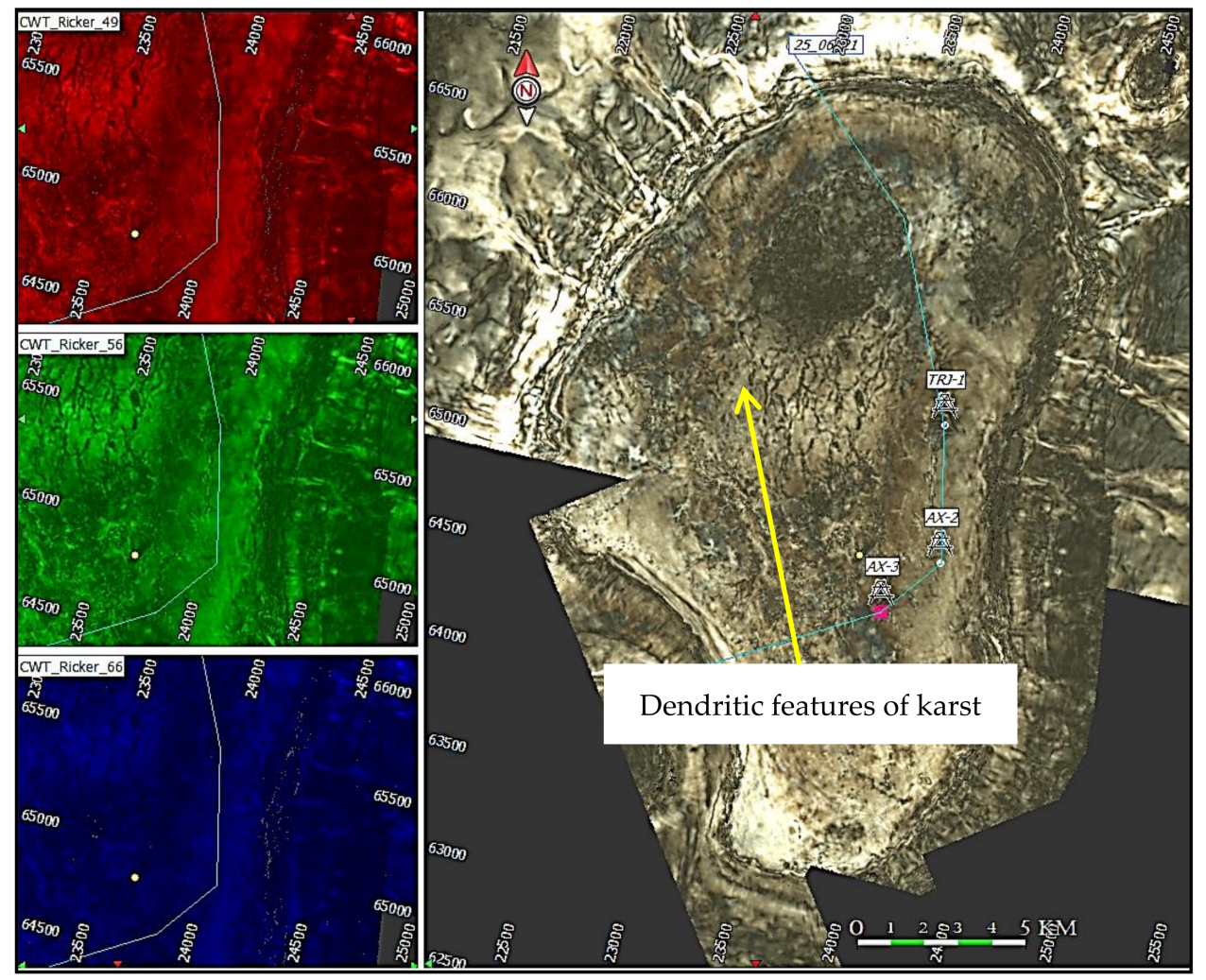

Figure 8. Red, green and blue (RGB) blending technique and co-rendering of extracted frequencies in real-time. 
Short-time Fourier transform (STFT) also known as fast Fourier transform (FFT) is one of the most commonly used spectral decomposition techniques to decompose nonstationary signals. STFT divides non-stationary signals into small segments (considered as stationary parts) and calculate Fourier transform for each segment [25]. The other spectral decomposition technique uses in this analysis known as continuous wavelet transform (CWT) convolutes the seismic trace with a defined wavelet at the frequency $\omega$. Two types of wavelet are available, the Morlet wavelet and the Ricker wavelet. The Ricker wavelet results in a strong time resolution while the Morlet wavelet is more accurate in the frequency domain. Karst geobody in both Jintan and M1 platforms were then quantified in percentages manually by using grid paper to suggest which spectral decomposition technique could delineate the most karst features.

\subsection{Cross Plot}

Karst geobodies were extracted based on the dendritic features identified in both the Jintan and M1 fields by using automatic geobody extraction module in PaleoScan ${ }^{\mathrm{TM}}$ software (Figure 9). The automatic geobody process is based on a cross-plot technique that uses blending of objects frequencies. The blending allows object classification using object's properties or attributes. The blending of each frequency which correspond with the dendritic features is defined as a class. The extracted karstic geobodies are then filtered and quality checked manually before proceeding to automatic volumetric calculation. The filtering process is to ensure the extracted geobodies are real karst not seismic noise.

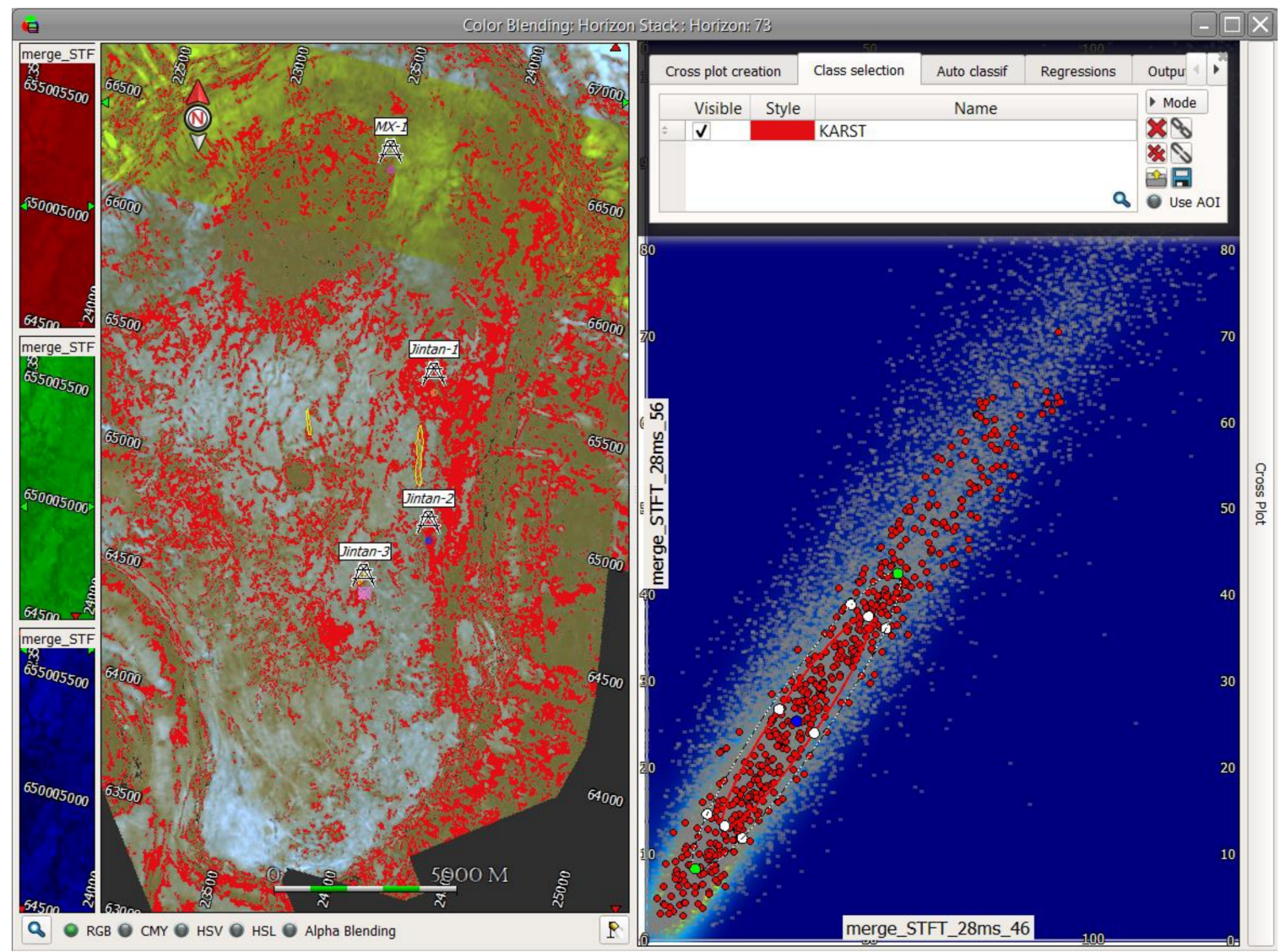

Figure 9. Karst geobody extraction module done in PaleoScan ${ }^{\mathrm{TM}}$ software before manual filtration and QC were done. 


\section{Results and Discussions \\ 4.1. Loss Circulation Depth, Thin Sections and Core Description Analysis}

Final well reports of Jintan-1, Jintan-2, Jintan-3, and M1-1 wells were studied to preliminary identify possible karst intervals and their corresponding depths. Jintan-3 well experienced lost circulation at $1869 \mathrm{~m}$ and was prematurely terminated to avoid further losses after it has experienced a minor loss at a rate of approximately $300 \mathrm{bbl} / \mathrm{min}$. The depth at which the loss occurred was recorded as a marker in Jintan-3 well for well to seismic correlation. The result showed that the lost circulation depth marker falls on the prominent dendritic features (Figure 10). Hence, it is important to avoid dendritic features on seismics. It is best to have possible karst features analysis/interpretations activity before the well development planning to avoid drilling issues which are also part of the time and cost optimization strategy.

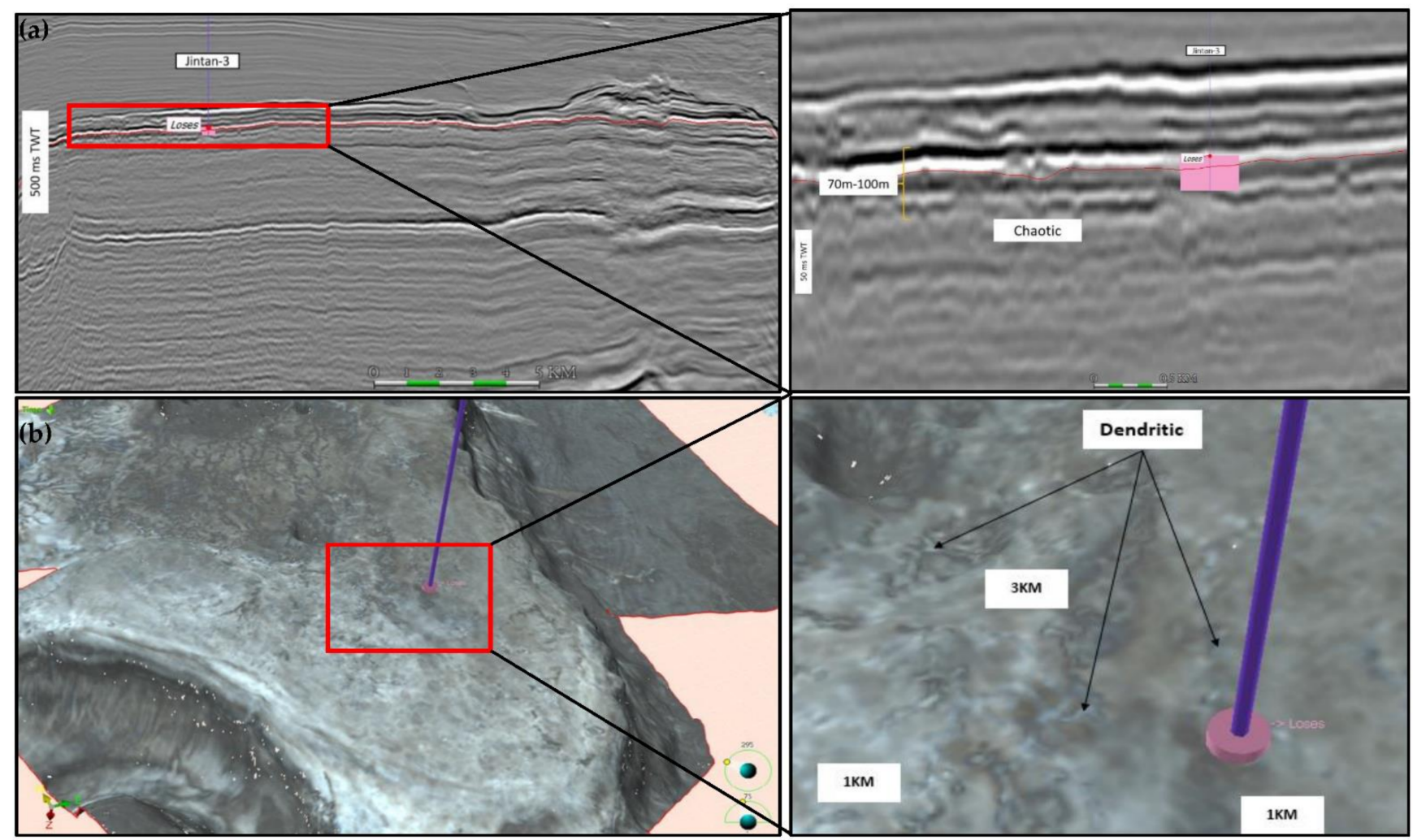

Figure 10. (a) The lost circulation depth marked at Jintan-3 well falls on the chaotic seismic facies which revealed the approximate height of the cavern karst geobodies are 70-100 m. Horizon marked in red is the interpreted horizon exactly on the losses depth. (b) Time slice of the interpreted horizon show that the loss depth marked in pink falls within the prominent $1-3 \mathrm{~km}$ long dendritic features.

Quantitative analysis on thin sections revealed that vuggy and moldic porosity in both wells are $25 \%$ of total pore types in Jintan-2 and $29 \%$ of total pore types in Jintan-3. Vugs of 2-4 mm in size with 1-2 mm moldic pore size and blocky calcite precipitates on the interior of fossils/molds were observed, which indicated the apparent rapidity of the dissolution process occurring in mixing zone. Melim [26] in her petrographic analysis on mixing zone diagenesis in the subsurface of Florida and the Bahamas revealed a petrographic fabric of moldic porosity and blocky to dogtooth calcite cementation which are similarly observed on Jintan-2 (Figure 11) and Jintan-3 (Figure 12) wells.

Core description analysis on Jintan- 2 and Jintan-3 wells revealed up to $10 \mathrm{~m}$ of chalkified and rubble interval as well as $\geq 0.5-1 \mathrm{~cm}$ large vugs and moldic porosity observed which confirmed the existence of a dissolution karstification process on the platforms (Figure 13). 


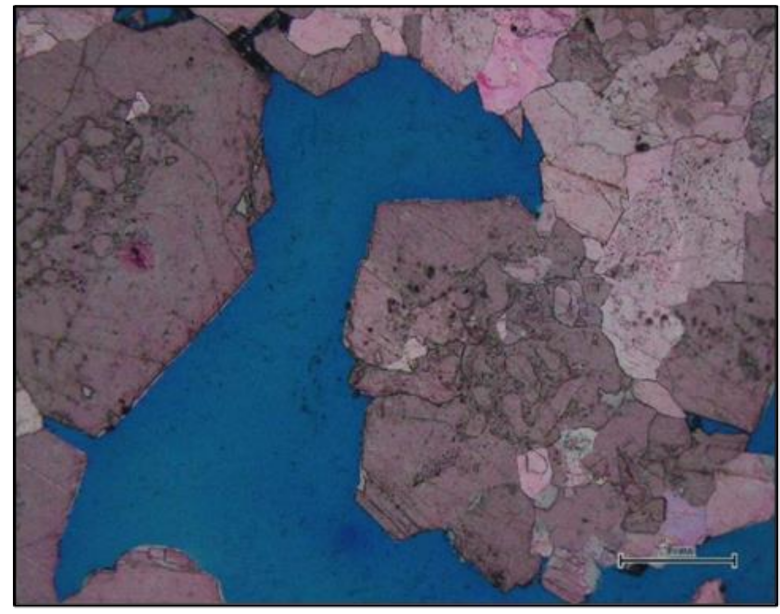

(a)

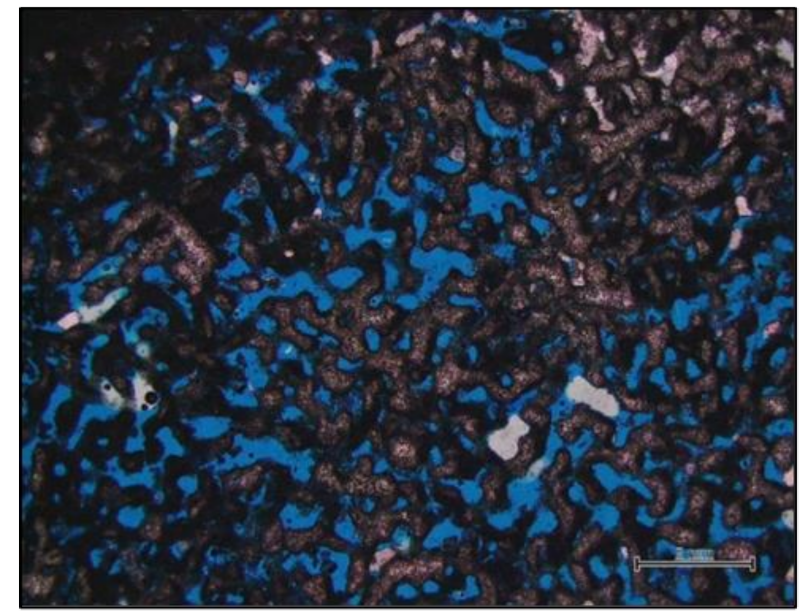

(b)

Figure 11. (a) Vug size of $4 \mathrm{~mm}$ observed on thin section in Jintan-2 well at $1649.6 \mathrm{~m}$ depth. (b) Moldic porosity of coral growth framework pore type observed on thin section in Jintan-2 well at $1680.8 \mathrm{~m}$ depth.

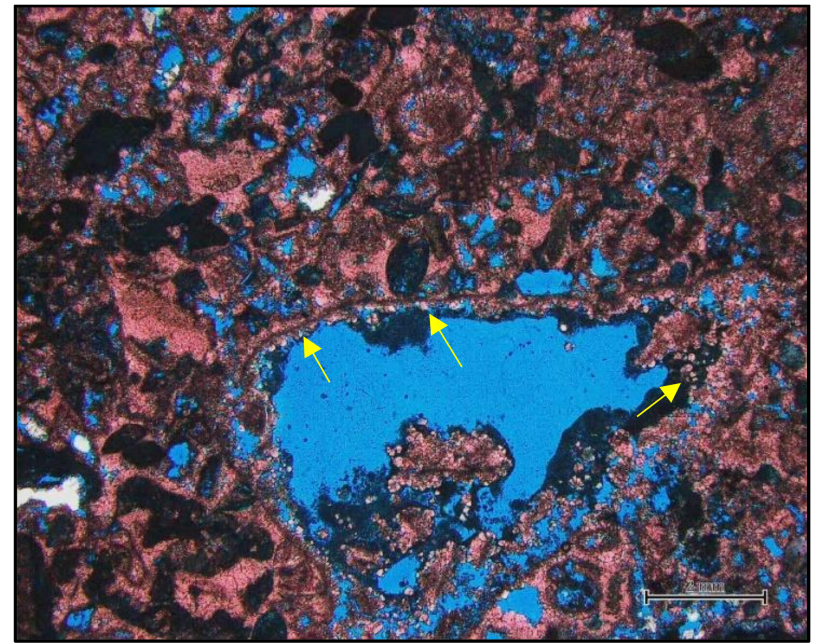

(a)

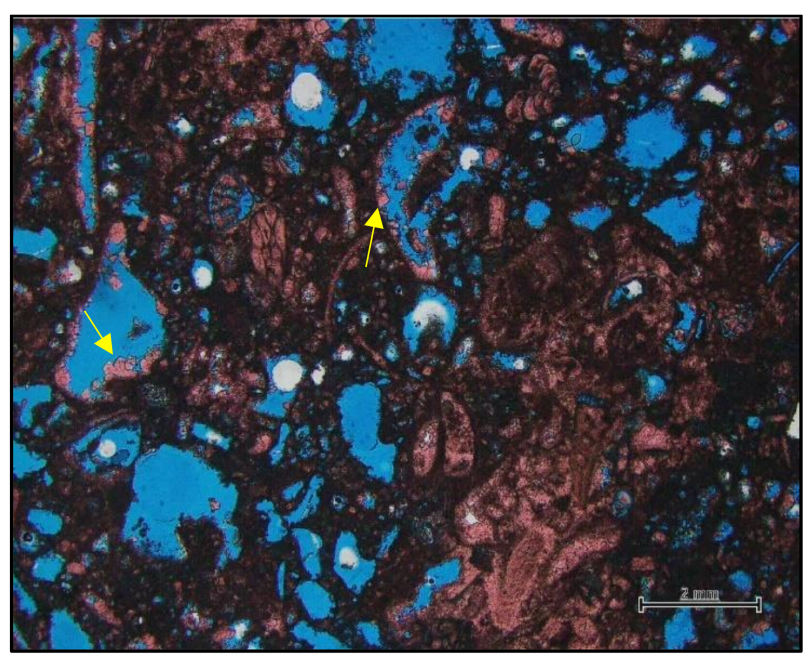

(b)

Figure 12. (a) More than $2 \mathrm{~mm}$ wide moldic porosity resulting from the dissolution of red algae and filled with blocky calcite cements (yellow arrow) are observed in a thin section at Jintan-3 well (1778.38 m depth). (b) More than 10 bioclasts dissolved and some of the pore filled with blocky calcite cements (yellow arrow) observed on thin section at Jintan-3 well at $1829.05 \mathrm{~m}$ depth.



(a)



(b)

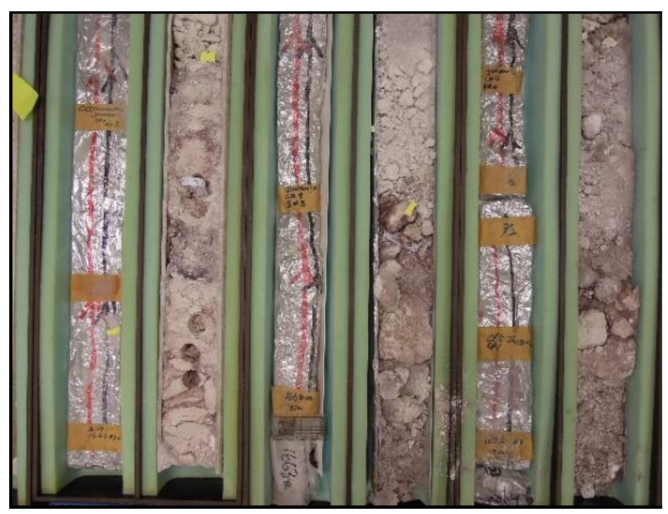

(c)

Figure 13. (a) Chalkified intervals observed in Jintan-2 well between 1662.97-1664.6 m depth (b) Rubble core observed in Jintan-3 well at 1792.4-1791 m depth (c) $\geq 0.5-1 \mathrm{~cm}$ large vugs and moldic porosity observed in Jintan-3 well at $1672.5 \mathrm{~m}$ depth. 


\subsection{Spectral Decomposition Short-Time Fourier Transform (STFT), Continuous Wavelet Transform (CWT) Morlet, and CWT Ricker Methods}

Three methods of spectral decomposition have been applied on the Jintan and M1 3D seismic cube (Figure 14). The STFT method utilized frequencies of 46, 54, and $60 \mathrm{~Hz}$, CWT Morlet wavelet with frequencies of 63,65 and $67 \mathrm{~Hz}$ and CWT Ricker wavelet with frequencies of 49, 56, and $66 \mathrm{~Hz}$. Analysis showed that the STFT method delineated more prominent karst on the Jintan platform as highlighted in yellow (Figure 14a). CWT Morlet wavelets delineated most karst features on the M1 platform particularly closer to the reef rim area (Figure 14b). Meanwhile, the CWT Ricker wavelet method delineated fewer karst features compared to the other two methods (Figure 14c). Quantitative analysis suggested that the STFT method delineates most karst features compared to the CWT method (Table 2).

\subsection{Evolution of Karst on Jintan and M1 Platform}

Karst evolution of the Jintan and M1 platforms was analyzed by comparing the volume of karst features on three selected karst horizons K1, K2 and K3. In this analysis, spectral decomposition by using STFT with frequencies of 46,54 , and $60 \mathrm{~Hz}$ was applied on the seismics. Horizon slices of K1, K2, K3 were interpreted on the RGB Blending viewer. K3 horizon falls in between seismic unit (SU) 3 and SU 4, K2 horizon falls on the highly karstified intervals of SU 4 and SU 5 while K3 horizons fall in between SU 5 and SU 6 as interpreted by [12]. Karst features on the three horizons were discussed and quantified in detail to understand the development of karst in the platforms (Figure 15).

Interpretation of the K1, K2, and K3 time slices in Figure 16 showed that the karst features were more prominent and well-developed on the K2 horizon. K1 horizon karst mostly developed on the Jintan platform and comprised 1-2 km-long dendritic patterns. The dendritic features were mainly observed in the lagoonal area of Jintan and M1 platforms. Along the K2 horizon, karst started to develop more on M1 platform especially closer to the reef rim area. Karst in K2 horizon showed a continuous dendritic pattern between 3-5 km-long on the Jintan platform. Interpretation of the $\mathrm{K} 3$ horizon revealed circular features of less than $1 \mathrm{~km}$ in diameter which are most likely sinkhole or cavern type karst on the Jintan lagoonal area. Spectral decomposition techniques applied during seismic interpretation has proven to be one of the best techniques to delineate the karst features on carbonate platforms. Table 3 summarizes the quantitative seismic interpretation of karst features on both platforms.

Table 2. Quantitative interpretation by using manual gridding calculation of the karst features delineates by short-time Fourier transform (STFT), continuous wavelet transform (CWT) Morlet, and CWT Ricker spectral decomposition techniques.

\begin{tabular}{ccc}
\hline Methods & Karst \% on Jintan & Karst \% on M1 \\
\hline STFT & 65 & 50 \\
CWT Morlet & 52 & 51 \\
CWT Ricker & 42 & 36 \\
\hline
\end{tabular}

\subsection{Volumetric Estimation of Karst}

This analysis aims to provide a volumetric estimation of the karst geobodies on the Jintan and M1 platforms. Figure 17 displays the karst geobody that has been selected on both platforms. Automatic volume calculation in the software estimated a total volume of $1.45 \times 10^{7} \mathrm{~m}^{3}$ and a total surface area of $66.66 \mathrm{~km}^{2}$. 


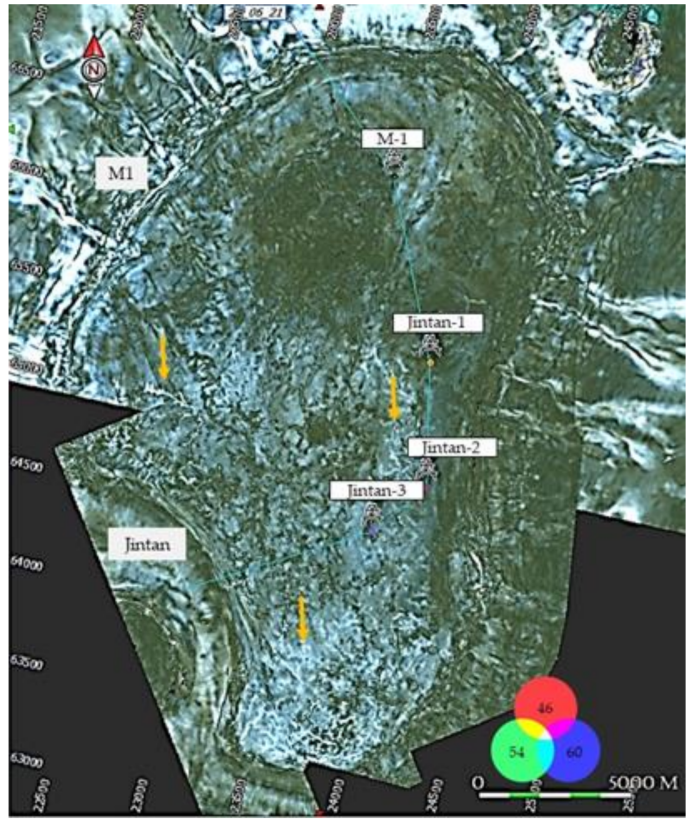

(a)

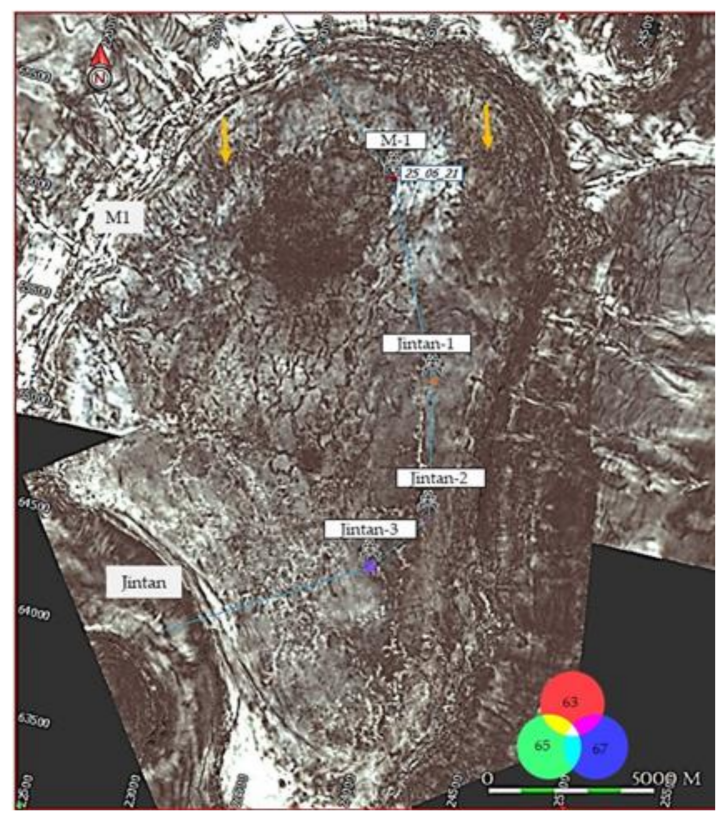

(b)

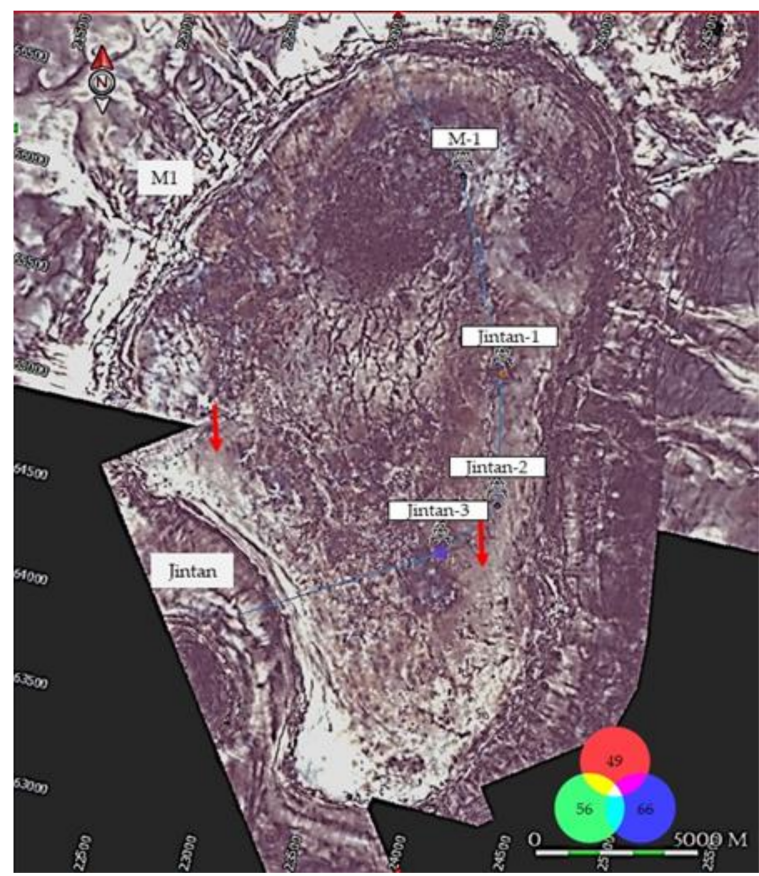

(c)

Figure 14. (a) STFT method delineates the most karst features especially on Jintan platform as highlighted in the yellow arrow. (b) CWT Morlet wavelet delineates most karst features in M1 near to the reef rim as highlighted in yellow. (c) CWT Ricker wavelet delineates fewer karst features compared to STFT and CWT Morlet where the karst features were missing on the red arrow area. 


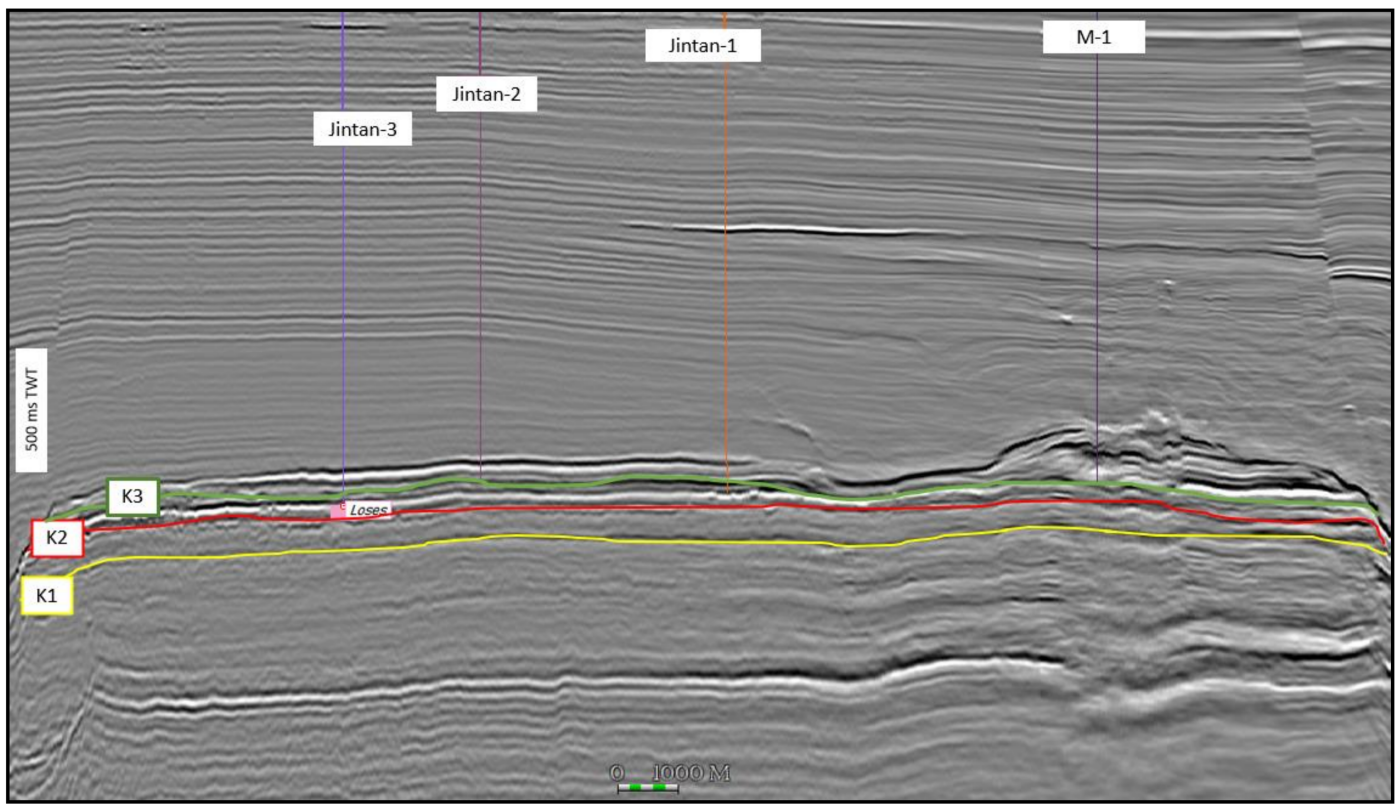

Figure 15. Horizon K1, K2 and K3 picked on different seismic unit (SU) intervals.

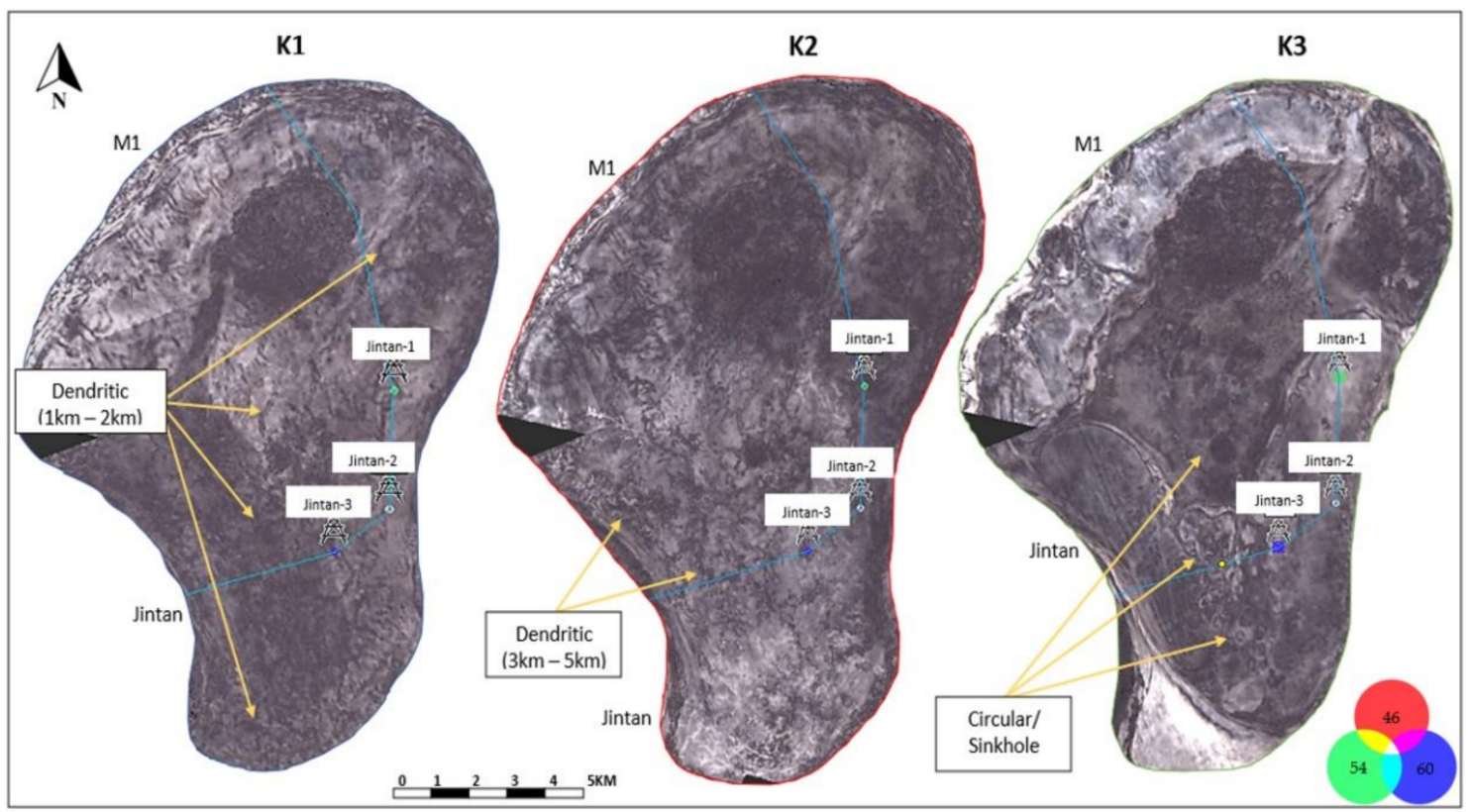

Figure 16. Evolution of the karst features on selected $\mathrm{K} 1, \mathrm{~K} 2$, and $\mathrm{K} 3$ horizons show that the karst features are welldeveloped and more prominent on the K2 horizon, highlighting that the heavily karstified intervals falls in between SU4 and SU5 as interpreted by [10].

Table 3. Quantitative interpretation of the karst features observed on Jintan and M1 seismics.

\begin{tabular}{|c|c|c|c|}
\hline Platform & Shape & $\begin{array}{l}\text { Quantitative } \\
\text { Interpretation }\end{array}$ & $\begin{array}{c}\text { Most Concentrated } \\
\text { Area }\end{array}$ \\
\hline \multirow[t]{2}{*}{ Jintan } & Dendritic & $\begin{array}{l}\geq 70-100 \mathrm{~m} \text { deep } \\
3-5 \mathrm{~km} \text { long } \\
\geq 500 \mathrm{~m} \text { wide }\end{array}$ & Lagoon \\
\hline & Circular/sinkhole & $\leq 1 \mathrm{~km}$ in diameter & Lagoon \\
\hline M1 & Dendritic & $\begin{array}{l}1-2 \mathrm{~km} \text { long } \\
\geq 500 \mathrm{~m} \text { wide }\end{array}$ & $\begin{array}{c}\text { Close to reef rim and } \\
\text { lagoon }\end{array}$ \\
\hline
\end{tabular}






Figure 17. The extracted dendritic karst geobodies from Jintan and M1 platforms which were utilized for the volumetric estimation.

\section{Conclusions}

Comprehensive analysis of the integrated multiscale dataset has led to the quantitative description of karst features on the Jintan and M1 carbonate platforms (Table 4).

Table 4. Karst features observed on Jintan and M1 fields from the multiscale dataset.

\begin{tabular}{|c|c|}
\hline Data & Karst Features \\
\hline Drilling parameters & $\begin{array}{c}\text { Jintan-3 well reported lost circulation at depth of } 1869 \mathrm{~m} \text { at a rate } \\
\text { of approximately } 300 \mathrm{bbl} / \mathrm{min} .\end{array}$ \\
\hline Thin sections & $\begin{array}{l}2-4 m m \text { vugs and moldic pore size observed (leaching) with } 25 \% \\
\text { and } 29 \% \text { of vuggy and moldic porosity in the Jintan wells. }\end{array}$ \\
\hline Core & $\begin{array}{l}\geq 0.5-1 \mathrm{~cm} \text { vugs and moldic porosity observed. } \\
\text { Rubbles and chalkified intervals described. }\end{array}$ \\
\hline Seismic & $\begin{aligned} \text { Dendritic: } \geq 70-100 \mathrm{~m} \text { deep, } 1-5 \mathrm{~km} \text { length and } \geq 500 \mathrm{~m} \text { wide. } & \text { Sinkhole/circular: } \leq 1 \mathrm{~km} \text { in diameter. }\end{aligned}$ \\
\hline Volumetric Calculations & $\begin{array}{l}\text { Volume of the karst geobodies is } 1.45 \times 107 \mathrm{~m}^{3} \text { with a total area of } \\
66.66 \mathrm{~km}^{2} .\end{array}$ \\
\hline
\end{tabular}

Analysis of the seismic cube using three methods of spectral decomposition suggested that the STFT method was most likely to delineate more karst features compared to the CWT method. The evolution of karst interpreted on the KI, K2 and K3 horizons indicated that the dendritic features were well-formed and most prominent in the K2 horizon which falls below the backstepping intervals of both platforms. K1 horizon revealed circular shaped features, most probably sinkhole structures in the lagoonal area of the Jintan platform. The presence of karst features was more prominent in the lagoonal area of both platforms as well as the reef rim in the M1 platform. 
The STFT spectral decomposition method on seismics has improved the quantitative analysis on karst features of carbonate platforms. This study has also emphasized the importance of an integrated geological and geophysical study crucial for geobody characterization especially on carbonate platforms.

The study on karst in Central Luconia has been undertaken since the 1980s. However, the nature of the karst morphology in Central Luconia remains controversial. There is limited evidence on the influence of tectonism on karst morphology. Petrographic analysis revealed large vugs and moldic pores with blocky to dogtooth calcite cement that was precipitated on the interior of fossils/molds observed, which suggests the apparent rapidity of dissolution within the mixing zone. Thus, it is possible that the karst morphology in Jintan and M1 platforms originated from a mixing zone karst.

Furthermore, the karst features observed are dendritic features unlike the flank margin or banana hole caves features as observed in Bahamas [16]. The large size of the Jintan platform could possibly allow the development of conduit flow and produce traditional epigenic cave systems that discharge the freshwater lens by specific turbulent flow routes, which in turn are fed by diffuse flow in the island interior [17]. The conduit flow has allowed the karst to be developed, and hence supported the argument that the karst morphology in Central Luconia developed under the mixing zone conditions.

Author Contributions: Conceptualization, S.S.A.R., S.B.B., G.J.S., M.C.P. and R.R.; methodology, S.S.A.R., M.H.H., M.C.P.; software, R.R.; validation, R.R., G.J.S.; formal analysis, S.S.A.R.; investigation, S.S.A.R., S.B.B., G.J.S.; resources, N.H.M.J.; data curation, S.S.A.R., S.B.B., G.J.S.; writingoriginal draft preparation, S.S.A.R.; writing—review and editing, G.J.S., R.R.; visualization, M.H.H.; supervision, M.H.H., N.H.M.J., M.C.P.; project administration, S.S.A.R., S.B.B.; funding acquisition, N.H.M.J. All authors have read and agreed to the published version of the manuscript.

Funding: This research was funded by YUTP-FRG Grant titled Prediction of Karst in Carbonate Reservoir Buildup of Central Luconia with the cost center 015LC0-007.

Institutional Review Board Statement: Not applicable.

Informed Consent Statement: Not applicable.

Data Availability Statement: Thank You to PETRONAS MPM for permission to used proprietary data for this research.

Acknowledgments: The authors are thankful to Universiti Teknologi PETRONAS (UTP), Institute of Hydrocarbon Recovery (IHR), Geoscience Department, and South East Asia Clastic \& Carbonate Research Laboratory (SEACARL) for providing the facilities to support this research work. Thank You to PETRONAS MPM for permission to used proprietary data for this research. We extend our thanks to Eliis for providing PaleoScan ${ }^{\mathrm{TM}}$ software to conduct this research. This research work is funded by YUTP grant to Universiti Teknologi PETRONAS.

Conflicts of Interest: The authors declare no conflict of interest.

\section{References}

1. Mylroie, J.E.; Carew, J.L. Karst development on carbonate islands. AAPG Mem. 1995, 63, 55-76.

2. Columbia, B. Karst Management Handbook for British Columbia, 1st ed.; Ministry of Forests: Victoria, BC, Canada, 2003 ; pp. 1-69.

3. Ford, D.; Williams, P.D. Karst Hydrogeology and Geomorphology; John Wiley \& Sons: Hoboken, NJ, USA, 2013.

4. Palmer, A.N. Variation in rates of karst processes. Acta Carsologica 2007, 36, 15-24. [CrossRef]

5. Epting, M. Sedimentology of Miocene Carbonate Buildups, Central Luconia, Offshore Sarawak. Bull. Geol. Soc. Malays. 1980, 12, 17-30. [CrossRef]

6. Vahrenkamp, V.C. Miocene carbonates of the Luconia province, offshore Sarawak: Implications for regional geology and reservoir properties from strontium-isotope stratigraphy. Bull. Geol. Soc. Malays. 1998, 42, 1-13. [CrossRef]

7. Kosters, M.; Hague, P.F.; Hofmann, R.A.; Hughes, B.L.; Berhard, S.S. Integrated Modeling of Karstification of a Central Luconia Field, Sarawak. In Proceedings of the International Petroleum Technology Conference, Kuala Lumpur, Malaysia, 3-5 December 2008.

8. Ting, K.K.; Chung, E.; Al Jaaidi, O. Evolution and controlling factors of Miocene carbonate build-up in Central Luconia, SE Asia: Insights from integration of geological and seismic characterization. In Proceedings of the Integrated Petroleum Engineering and Geosciences (ICIPEG), Kuala Lumpur, Malaysia, 16 June 2010. 
9. Chung, E.; King, T.K.; AlJaaidi, O. Karst Modeling of a Miocene Carbonate Build-Up in Central Luconia, SE Asia: Challenges in Seismic Characterisation and Geological Model Building. In Proceedings of the International Petroleum Technology Conference, Bangkok, Thailand, 7-9 February 2012.

10. Jamaludin, S.N.F.; Mubin, M.; Latiff, A.H.A. Imaging of karst on buried Miocene Carbonate Platform. In Proceedings of the IOP Conference Series: Earth and Environmental Science, Bali, Indonesia, 20-21 May 2017. [CrossRef]

11. Warrlich, G.M.; Adams, E.W.; Ryba, A.; Tam, T.; Ting, K.K.; Tang, H.K. What matters for flow and recovery in carbonate gas reservoirs: Insights from the mature Central Luconia Province, offshore Sarawak, Malaysia. AAPG Bull. 2019, 103, 691-721. [CrossRef]

12. Yusliandi, A.; Sautter, B.; Poppelreiter, M.C. The various controls on the platform architecture of carbonate buildups in the Central Luconia Province, offshore Sarawak. Pet. Coal 2019, 61, 1425-1437.

13. Rahman, S.S.A.; Beg, M.A.; Soto, G.J.; Bing, S.B.; Lubis, L.A.; Poppelreiter, M.C. Seismic multiattributes characterisation of Karst distribution pattern in an isolated Middle Miocene carbonate platform: FX field, Central Luconia Province Malaysia. Pet. Coal 2021, 63, 139-150.

14. Makhankova, A.; Sautter, B.; Mathew, M.; Menier, D.; Poppelreiter, M. Seismic stratigraphy and sedimentology of a Miocene carbonate platform in Luconia, South China Sea. Geol. J. 2021, 56, 1-17. [CrossRef]

15. Warrlich, G.E.; Taberner, C.O.; Asyee, W.E.; Stephenson, B.; Esteban, M.A.; Boya-Ferrero, M.A.; Dombrowski, A.N.; Van Konijnenburg, J.H. The impact of postdepositional processes on reservoir properties: Two case studies of Tertiary carbonate buildup gas fields in Southeast Asia (Malampaya and E11). In Cenozoic Carbonate Systems of Australasia; Society for Sedimentary Geology: Broken Arrow, OK, USA, 2010; Volume 95, pp. 99-127.

16. Mylroie, J.R.; Mylroie, J.E. Development of the carbonate island karst model. J. Cave Karst Stud. 2007, 69, 59-75.

17. Larson, E.B.; Mylroie, J.E. Diffuse versus conduit flow in coastal karst aquifers: The consequences of island area and perimeter relationships. Geosciences 2018, 8, 268. [CrossRef]

18. Teillet, T.; Fournier, F.; Borgomano, J.; Montaggioni, L. Seismic-based paleoenvironmental reconstructions of carbonate systems: Pitfalls, limitations and perspectives-Reply to the comments on "Development patterns of an isolated oligo-mesophotic carbonate buildup, early Miocene, Yadana field, offshore Myanmar". Mar. Pet. Geol. 2020, 124, 104816. [CrossRef]

19. Bashir, Y.; Faisal, M.A.; Biswas, A.; abbas Babasafari, A.; Ali, S.H.; Imran, Q.S.; Ehsan, M. Seismic expression of miocene carbonate platform and reservoir characterization through geophysical approach: Application in central Luconia, offshore Malaysia. J. Pet. Explor. Prod. 2021, 11, 1533-1544.

20. Soto, G.J.; Beg, M.A.; Pöppelreiter, M.C.; Rahmatsyah, K. Multiple Point Statistics Carbonate Facies Modelling Workflow using Core Data and Spectral Decomposition Attributes: A Case Study from TX Field in Central Luconia Province, Malaysia. Pet. Coal 2020, 62, 1209-1224.

21. Othman, A.A.; Fathy, M.; Maher, A. Use of spectral decomposition technique for delineation of channels at Solar gas discovery, offshore West Nile Delta, Egypt. Egypt. J. Pet. 2016, 25, 45-51. [CrossRef]

22. Vahrenkamp, V.C.; Frank, D.; Peter, D.; Mark, N.; Paul, C. Growth architecture, faulting, and karstification of a middle Miocene carbonate platform, Luconia Province, offshore Sarawak, Malaysia. AAPG Mem. 2004, 81, 329-350.

23. Pauget, F.; Lacaze, S.; Valding, T. A global approach in seismic interpretation based on cost function minimization. In SEG Technical Program Expanded Abstracts; Society of Exploration Geophysicists: Tulsa, OK, USA, 2009; pp. $2592-2596$.

24. Ellaithy, T.; Prexl, A.; Daynac, N. A review of "global" interpretation methods for automated 3D horizon picking. Semathic Sch. 2006, 30, 38-47.

25. Shokrollahi, E.; Zargar, G.; Riahi, M.A. Using continuous wavelet transform and short time Fourier transform as spectral decomposition methods to detect of stratigraphic channel in one of the Iranian south-west oil fields. Int. J. Sci. Emerg. Technol. 2013, 5, 291-299.

26. Melim, L.A.; Swart, P.K.; Eberli, G.P. Mixing-zone diagenesis in the subsurface of Florida and the Bahamas. J. Sediment. Res. 2004, 74, 904-913. [CrossRef] 